\title{
The Effect of Leg Circuits Exercise Toward Strength of Limbs Muscles of Female Students Volley Ball Team
}

\author{
Cevvin Septa Edran, ${ }^{*}$ Drs.Slamet, M.Kes, AIFO, Ardiah Juita, S.Pd, M.Pd \\ Study Program Education of Coaching Sports Faculty of Teacher \\ Training and Education \\ University Riau
}

Email:cevvinseptaedran@gmail.com

\begin{abstract}
The purpose of this research is to know the effect of Legs Circuits exercises on the strength of limbs muscles of SMA N 3 PEKANBARU Women's volleyball team. Type of research use experiment with One Group Pretest Posttest Only Design that involved eight students. The instruments used in this research were Leg dynamometer, which is aimed to measure the strength of limb muscles. The data was analyzed by using a statistic to examine the normality with lilie for test on the significant level $0,05 \alpha$.

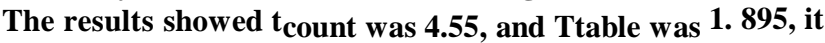
means that $t_{\text {count }}>$ ttable. Based on the statistic data analysis, the mean of the pre-test was 55. 31, and the mean of the post-test was 61. 25. In conclusion, there was the effect of $t h$ e Leg Circuit exercise toward the strength of limbs muscle of SMAN3 woman's volleyball club.
\end{abstract}

Keywords - Leg Circuit, Strenght of limbs muscle

\section{INTRODUCTION}

Sport is a form of activity that is beneficial and can increase physical fitness and fitness. In addition to forming character, behavior, personality, discipline and personality, exercise can also improve the ability of thinking power and the development of optimal achievement. This fact also occurs in "solving sports performance problems, various related sciences, such as sportsmen, are reviewed, researched and finally applied to support the achievement of the optimal subject matter" [1]. "Sports are forms of physical activities that are "contained in games, competitions, and intensive physical activities in order to obtain recreation, victory and optimal achievement" [2].

Through the achievements of the Indonesian nation's Sports known by other nations, this is in accordance with the Law of the National Sports System of the Republic of Indonesia No. 3 of 2005 article 4 on the basis, functions and objectives of sport, namely: "National sports aimed at maintaining and improving physical health and fitness, achievement of human quality, instilling moral values and noble character, discipline, sportsmanship, strengthening brotherhood and fostering national unity, strengthen national defense, and raise the dignity, dignity and honor of the nation.

Through the achievements of the Indonesian nation's Sports known by other nations, this is in accordance with the Law of the National Sports System of the Republic of Indonesia No. 3 of 2005 article 4 on the basis, functions and objectives of sport, namely: "National sports aimed at maintaining and improving physical health and fitness, achievement of human quality, instilling moral values and noble character, discipline, sportsmanship, strengthening brotherhood and fostering national unity, strengthen national

defense, and raise the dignity, dignity and honor of the nation ". One branch of sport that needs to be improved is the Bolavoli branch. Bolavoli games are a type of team sport that uses large balls, requires a certain size of the field, and is played in groups.

Bolavoli game when it has been played by the players, it is very visible that the player performs a motion activity that requires speed and strength, "for example when he hits the ball, requires strength when he hits the ball hard, requires strong endurance when playing in sufficient tempo long, and requires power in the leg muscles when jumping to hit the ball" [3]. To be a good volleyball team needed the ability to support good physical condition. To be able to face the match with good performance requires technical, physical, mental, technical and mental maturity. One of the factors that is very influential in dealing with good performance in addition to technical, physical, and mental factors is physical condition.

Considering volleyball is a type of sport that relies heavily on physical conditions, the player's physical condition is very important in supporting team effectiveness. Physical condition is a unified whole of components which cannot be separated, both its improvement and its maintenance. "Components physical condition components include: Strength (strength), Endurance (endurance), Muscle Power (power), Speed (Speed), Flexibility (flexibility), Agility (agility), Coordination (coordination), Balance (balance), Accuracy and Reaction"[1]. There are four types of equipment that must be possessed if a person will achieve a maximum achievement, namely: "1) Physical development (physical build-up), 2). Technical development (technical buil-up), 3) Mental development (mental build-up), 
4). Winner's pool" [4]. One of the basic factors that influences the ability of an athlete in the Bolavoli branch is strength. "Strength is a component of a person's physical condition regarding his ability to use muscles to accept workload" [1]. Strength in leg muscles in the game Bolavoli is needed, because strength in a volleyball player can help strengthen joint stability. The strength of the leg muscles increases the effectiveness of the motion which is able to support the body weight. The higher the ability of one's leg muscle strength the more stable his body will be. Based on observations made on the "Women's Volleyball Team of SMA N 3

Pekanbaru", I saw the lack of leg muscle strength of the students, this can be observed from the inability of the students to bear the burden of their own bodies, almost all students during the competition put their body weight into

the right and left sides of the body to move his body weight and almost last throughout the match session.

Another thing that can be explained is that when players make a landing after making a low jump, most of them are unable to hold their body weight in the process of landing (falling). The inability of students will of course be easily utilized by the opposing team, considering the physical

condition (strength) is a basic physical component that must be possessed by every beginner athlete before proceeding to advanced physical conditions such as power. Based on this explanation, the researchers tried to implement a Leg Circuit training program. "Leg Circuit is an exercise program that aims at the basic physical components of strength or Strength" [5].

The types of exercises include: a) Body-weight squat, b) Lunge, c) Step-up, d) Squat jump. Seeing the characteristics of the form of training, concepts, basic training and its suitability with existing problems, the author wants to provide Legs Circuits training for the female volleyball team

in SMA N 3 Pekanbaru to increase leg muscle strength by

appealing to the research title "The Effect of Legs Circuits Exercise on Leg Muscle Strength on the Team Women's volleyball High School N 3 Pekanbaru ".

\section{METHOD}

This study uses a one-group pretest-posttest design approach. In the design there is a pre-test, before it is given treatment. Thus the results "of the treatment can be known to be more accurate, because it can compare with the situation before being given" [6]. The population in this study was the female volleyball player in SMA N 3 Pekanbaru, the sample

in this study was the students of SMA N 3 Pekanbaru who actively participated in the training which consisted of 8 players. The sampling technique uses Saturated Sampling where all members of the population are used as samples. The instrument used in this study was the Leg Dynamometer, which aims to measure leg muscle strength. After that, the data is processed statistically, to test normality with the lilifors test at a significant level of $0.05 \alpha$. The hypothesis proposed is that there is an influence of Leg Circuit training on the leg muscle strength of the women's Bolavoli team at SMA N 3 Pekanbaru.

\section{RESULT}

The variables in this study are Leg Circuit training, as the independent variable, while the Leg Muscle Strength as the dependent variable.

Based on the analysis of statistical data, there is an average pree-test of 55.31 and an average post-test of 61.25 , then based on the t-test analysis yields a t-test of 4.55 and ttable of 1,895, meaning tcount $>$ ttable. Thus, there is an effect of Legs Circuits training on leg muscle strength on the Women's Bolavoli Team at SMA N 3 Pekanbaru.

Leg Circuit is the basis for more specific strength training to be adjusted in terms of absolute strength and plyometrics. This is a program that has been used for many years to base strength and endurance strength. it is also a good tool for use in the recovery of low-level injuries in rebuilding the basic skills of training in preparation for playing again. From research to data processing after conducting research that

begins from data collection to data processing which is finally used as a benchmark for discussion of research results as follows: There is an influence of Leg Circuit training, (X) Against Limb Muscle Strength (Y ) In the Women's Volleyball Ball Team at SMA N 3 Pekanbaru, this can be seen from the average results of the pree-test of the Leg Dynamometer before being given treatment which is 55.31 and after being given treatment is 61.25. This shows that there is an influence between the two variables mentioned above. Hypothesis testing which shows the influence of Leg Circuit training, on the leg muscle strength in the women's volleyball team at SMA N 3 Pekanbaru, this illustrates that leg muscle strength can be affected by leg circuit training.

So with the Leg Circuit training pattern applied to the Women's Volleyball Team at SMA N 3 Pekanbaru, there is an increase in the muscle strength of the female students' limbs. This means that each exercise is certainly expected to improve the results achieved. Training is an iterative process and increases the potential for achieving maximum performance.

Based on the t-test, the tcount was 4.55. with a 1.895 table then HO is rejected and Ha is accepted, at an alpha level $(\alpha) 0.05$. It can be concluded that there is an effect of Leg Circuit training, on leg muscle strength in the Women's Bolavoli Team of SMA N 3 Pekanbaru.

\section{CONCLUSION}

Based on the analysis of the t test yielded a tcount of 4.55 and then compared with ttable at a significance level of $95 \%$ and $\mathrm{df}=\mathrm{n}-1$ of 1.895 stating tcount $>$ ttable. This means that Leg Circuit Training has an influence on leg muscle strength in the Women's Volleyball Team at SMA N 3 Pekanbaru. 
Based on these findings it can be concluded as follows: There is a significant influence between Leg Circuit Exercise (X) on leg muscle strength (Y) in Female Volleyball Team SMA N 3 Pekanbaru

\section{REFERENCES}

[1] Sajoto, Mochamad, "Pembinaan Kondisi Fisik Dalam Olahraga,’Semarang; IKIP Semarang.1988,pp,34-43.

[2] Kosasih, Engkos, “Teknik Dan Program Latihan,”Jakarta; Balai Pustaka, 1993, pp. 34.

[3] M. Muhyi Faruq, "Meningkatkan Kebugaran jasmani melalui permainan \& olahraga bola voli,’Jakarta,2008, pp. 67.

[4] Vern Gambetta, "Athletic Development: theart \& science offunctional sport conditioning," USA.2007, pp. 61.

[5] Sugiyono,"Metode Penelitian Kuantitatif Kualitatif Dan R\&D,'Bandung; Alfabeta, 2012,pp,48-54.

[6] M. N. A. Setiawan. "Increasing Aerobic Durability Skill by Practicing Extensive Interval Method for Volleyball Athlete in Rokan Hulu Regency", Applied Science and Technology, vol. 2, no. 1, pp. 129131, February. 2018. 